\title{
Fungsi Komunikasi dalam Organisasi Melalui Grup percakapan WhatsApp Civitas Academica Fakultas Psikologi Universitas Pancasila
}

\author{
Komarudin Subekti ${ }^{1}$, Ahmad Toni ${ }^{2}$ \\ 1,2Universitas Budi Luhur, Jakarta \\ 1․ㅡekti.nayottama@gmail.com, 2ahmad.toni@budiluhur.ac.id
}

Naskah diterima tanggal 03-12-2020, direvisi tanggal 18-02-2021, disetujui tanggal 28-02-2021

\begin{abstract}
Abstrak. Pentingnya berkomunikasi terlihat dari perkembangan teknologi komunikasi dan informasi yang semakin inovatif. Dalam mengatasi persoalan waktu dalam berkomunikasi, kemajuan teknologi komunikasi dapat menghapuskan batas-batas geografis atau wilayah. Munculnya alat-alat elektronik dengan sistem terkini menyebabkan teknologi komunikasi berkembang dengan pesat, contohnya adalah perkembangan ponsel pintar dan teknologi internet yang memudahkan orang dalam melakukan komunikasi tanpa dibatasi jarak dan waktu. Perkembangan teknologi komunikasi juga diikuti oleh kehadiran berbagai platform aplikasi obrolan yang banyak digunakan oleh individu, kelompok, maupun organisasi sebagai media komunikasi. Salah satu aplikasi obrolan yang menjadi favorit banyak orang dan digunakan untuk melakukan komunikasi serta berinteraksi oleh masyarakat, tidak terkecuali organisasi, adalah WhatsApp. Penelitian ini bertujuan untuk mengetahui fungsi komunikasi dalam organisasi dalam grup percakapan WhatsApp Civitas Academica Fakultas Psikologi Universitas Pancasila. Penelitian ini menggunakan pendekatan kualitatif metode deskriptif, dengan teknik pengumpulan data yaitu observasi partisipatif terhadap grup percakapan WhatsApp Civitas Academica Fakultas Psikologi Universitas Pancasila, wawancara kepada 5 informan yang berada dalam grup percakapan WhatsApp Civitas Academica Fakultas Psikologi Universitas Pancasila. Hasil penelitian ini menunjukkan bahwa fungsi komunikasi dalam organisasi melalui grup percakapan WhatsApp Civitas Academica Fakultas Psikologi Universitas Pancasila terdiri dari 4 fungsi komunikasi, yaitu: fungsi informatif, fungsi regulatif, fungsi persuasif dan fungsi integratif, yang bertujuan untuk memberikan perintah, instruksi pekerjaan, dan laporan pekerjaan.
\end{abstract}

Kata Kunci : fungsi komunikasi, komunikasi organisasi, whatsapp

Abstract. The importance of communication can be seen from the development of increasingly innovative communication and information technology. In overcoming the problem of time in communication, advances in communication technology can eliminate geographic or territorial boundaries. The emergence of electronic devices with the latest systems causes communication technology to develop rapidly, for example, the development of smartphones and internet technology which makes it easier for people to communicate without being limited by distance and time. The development of communication technology is also followed by the presence of various chat application platforms that are widely used by individuals, groups and organizations as a medium of communication. One of the chat applications that is a favorite of many people and is used to communicate and interact by the community, including organizations, is WhatsApp. This study aims to determine the function of communication within the organization in the WhatsApp chat group Civitas Academica, the Faculty of Psychology, Universitas Pancasila. This study uses a qualitative descriptive method approach, with data collection techniques, namely participatory observation of the WhatsApp chat group Civitas Academica Faculty of Psychology Universitas Pancasila, interviews with 5 informants who are in the WhatsApp chat group Civitas Academica Faculty of Psycholog Universitas Pancasila. The results of this study indicate that the communication function within the organization through the 
WhatsApp chat group Civitas Academica Faculty of Psychology Universitas Pancasila consists of 4 communication functions, namely: informative function, regulatory function, persuasive function and integrative function, which aims to provide orders, work instructions, and reports. profession.

Keywords : Communication Function, Organizational Communication, WhatsApp

\section{PENDAHULUAN}

Seperti yang sudah kita semua ketahui bahwa manusia adalah makhluk sosial. Kita, sebagai manusia, melakukan interaksi kepada manusia lainnya dengan berkomunikasi. Berkomunikasi tidak hanya saling berbicara atau mengobrol saja. Lewat tulisan, gambar, kedipan mata, lambaian tangan, mengangguk atau menggelengkan kepala juga bagian dari sebuah proses komunikasi. Berkomunikasi adalah kebutuhan yang mutlak bagi manusia untuk berinteraksi dan bersosialisasi, sesuai perannya sebagai makhluk sosial. Thomas M. Scheidel berpendapat, manusia berkomunikasi dalam rangka untuk mendukung dan menyatakan sebuah identitas diri, membangun sebuah kontak sosial dengan individu-individu di dekatnya dan memengaruhinya agar dapat berperilaku, merasa, berpikir seperti yang diinginkan. Namun pada dasarnya, manusia berkomunikasi bertujuan untuk mengendalikan lingkungan fisik dan psikologisnya (Mulyana, 2008).

Seiring dengan kemajuan zaman, kebutuhan pokok manusia juga bertambah. Selain sandang, papan, dan pangan, kini manusia juga memerlukan akses internet sebagai salah satu kebutuhan pokoknya. Internet saat ini memiliki peran yang sangat penting bagi kehidupan sosial, ekonomi, dan politik manusia di dunia. Setiap tahunnya, internet memberikan pengaruh yang sangat besar di dalam kehidupan manusia. Teknologi internet telah mengubah peradaban dunia dengan sangat cepat. Penggunaan internet juga telah memberikan pengaruh besar terhadap pola komunikasi manusia. Lewat internet, tidak ada lagi batasan bagi manusia untuk berkomunikasi.

Teknologi internet yang terus berkembang inilah yang membuat pola komunikasi semakin luas. Dari internet, kemudian lahir dan berkembang berbagai macam media yang menjadi tempat untuk berkomunikasi. Salah satunya adalah kemunculan media sosial yang saat ini telah mengubah pola dan perilaku manusia dalam berkomunikasi. Perubahan perilaku komunikasi yang dapat kita rasakan adalah berubahnya jaringan offline (tatap muka atau bertemu secara langsung) menjadi online lewat penggunaan media sosial dengan bantuan jaringan internet sehingga jarak dan waktu bukan lagi halangan dalam berkomunikasi.

Menurut Van Dijk, media sosial merupakan sebuah platform yang mengkhususkan diri pada kehadiran pengguna dan memfasilitasi mereka dalam beraktivitas juga berkolaborasi. Dari hal tersebut, kita dapat menyebut jika media sosial sebagai fasilitator atau medium daring yang berfungsi untuk memperkuat relasi antar penggunanya agar terbentuk pula ikatan sosial di antara mereka. Media sosial, semacam Facebook, Twitter, Instagram, Line, hingga WhatsApp dapat disebut sebagai situs sosial interaktif yang dapat membuat penggunanya bisa bertukar informasi, melakukan pertemanan, sampai membentuk sebuah jaringan sosial di dalam dunia virtual internet. Teknologi ini kemudian membuat setiap manusia dapat terhubung dalam berkomunikasi secara daring (Nasrullah, 2013).

Bala (2014) berpendapat jika media sosial mengarah kepada alat bagi masing-masing individu untuk saling berinteraksi yang di dalamnya mereka kemudian berbagi, membuat, dan saling tukar menukar informasi serta ide yang dilakukan lewat komunitas virtual dalam jaringan. Lebih lanjut, Hermawan (2009) menjelaskan bila pemanfaatan internet menggunakan media sosial sudah menciptakan apa yang disebut sebagai web forum yang pada akhirnya membentuk sebuah komunitas daring. Sama halnya dengan sebuah forum diskusi, web forum juga bisa menampung pendapat, ide, dan semua informasi dari anggota-anggotanya sehingga bisa saling berkomunikasi dan saling bertukar pikiran. Forum web daring umumnya memiliki hanya satu topik bahasan saja. Namun, tidak ada batasan sebuah topik untuk bisa berkembang dan meluas ke berbagai hal lainnya. Forum daring sejatinya adalah sebuah papan 
pengumuman yang ditampilkan dalam bentuk online. Semakin berkembangnya teknologi kemudian membuat forum daring memiliki fungsi yang lebih luas, tidak hanya sekadar untuk berbagi indormasi saja, tetapi juga dapat menjadi sarana akomodasi antar sesama penggunanya.

Seperti telah disinggung di atas, komunikasi bagi kehidupan manusia sangatlah penting. Bukan hanya komunikasi antar individu saja, tetapi juga komunikasi manusia di dalam organisasi (Muhammad, 2017). Penerapan komunikasi yang baik dapat membantu sebuah organisasi dalam meraih seluruh tujuannya. Lewat komunikasi, orang-orang yang ada di dalam organisasi dapat berinteraksi satu sama lain, mulai dari saling bertukar informasi, berpendapat, memberikan arahan atau instruksi, pelaporan pekerjaan, hingga saling memberikan motivasi. Di era sebelum kemajuan teknologi informasi dan komunikasi seperti sekarang ini, kegiatan komunikasi (individu, kelompok, atau organisasi) memang hanya bisa dilakukan secara langsung atau face to face. Dengan adanya perkembangan teknologi informasi dan komunikasi di era digital ini, masing-masing orang dapat berkomunikasi dan bertukar informasi secara bebas, tanpa dibatasi oleh ruang dan waktu.

Smartphone merupakan wujud nyata dari kemajuan teknologi saat ini yang diciptakan untuk mempermudah manusia dalam berkomunikasi. Sebagai alat komunikasi yang mendapat julukan "pintar" tentu smartphone memiliki banyak fitur dan keunggulan dibanding telepon genggam biasa. Smartphone tidak hanya berfungsi sebagai alat untuk menelepon atau mengirim pesan singkat saja, tetapi sudah berkembang menjadi ponsel yang jauh lebih canggih dengan adanya aplikasi-aplikasi dan fitur-fitur baru mulai dari game, foto, musik, video, sosial media, hingga instant messenger atau aplikasi obrolan yang dimanfaatkan untuk banyak kegunaan seperti mengobrol dan mengirim berbagai jenis file (Rahmansari, 2017).

Kehadiran media sosial sendiri juga tidak terlepas dari berbagai platform media yang disediakan oleh internet yang memudahkan setiap orang untuk saling berinteraksi satu sama lainnya dalam ranah virtual. Kehadiran smartphone yang memiliki fitur canggih, yaitu media sosial untuk melakukan komunikasi di ruang virtual atau online yang dapat dilakukan kapan pun dan di mana pun, kecanggihan ini memotivasi masyarakat, kelompok maupun organisasi untuk memenuhi kebutuhan komunikasinya. Salah satu aplikasi yang saat ini tengah ramai digunakan oleh masyarakat sebagai sarana komunikasi melakukan diskusi bersama teman, keluarga, kelompok sosial serta orang-orang yang tidak dapat dijangkau keberadaanya adalah aplikasi obrolan WhatsApp. WhatsApp merupakan sebuah aplikasi pengirim pesan instan dengan jaringan internet yang dapat digunakan pada smartphone, tablet dan komputer yang memungkinkan pengguna untuk bertukar pesan, gambar audio dan video. Aplikasi ini jug memberikan fasilitas untuk membuat grup percakapan (Jumrad \& Sari, 2019).

Melihat berbagai kemudahan dan manfaat yang ditawarkan, maka tak mengherankan jika WhatsApp digunakan oleh semua kalangan mulai dari remaja, dewasa, hingga yang tua. WhatsApp juga tidak terbatas oleh kelas sosial ekonomi tertentu, melainkan digunakan oleh semua kelas, mulai ekonomi rendah, menengah, hingga ekonomi atas. Pada perkembangan selanjutnya, aplikasi WhatsApp ini tidak hanya dimanfaatkan untuk berkomunikasi dan bertukar pesan, akan tetapi saat ini WhatsApp juga dimanfaatkan untuk kepentingan pekerjaan. Tidak jarang sebuah perusahaan atau instansi pemerintah menggunakan media ini untuk berkomunikasi dengan para staf/karyawan dan pegawai. (Rahmansari, 2017).

WhatsApp menjadi salah satu aplikasi percakapan terfavorit masyarakat Indonesia. Beradasarkan data dari Kementerian Komunikasi dan Informatika tahun 2019, 83\% dari 171 juta pengguna internet di Indonesia adalah pengguna WhatsApp (Barokah, 2019). Sedangkan berdasarkan laporan We Are Social dan Hootsuite dalam Digital 2020, WhatsApp menempati posisi kedua sebagai platform media sosial yang paling banyak digunakan. Sekitar $84 \%$ dari jumlah populasi masyarakat Indonesia aktif menggunakan WhatsApp. Dari sisi keaktifan pengguna, WhatsApp juga menempati posisi teratas (We Are Social, 2020). 


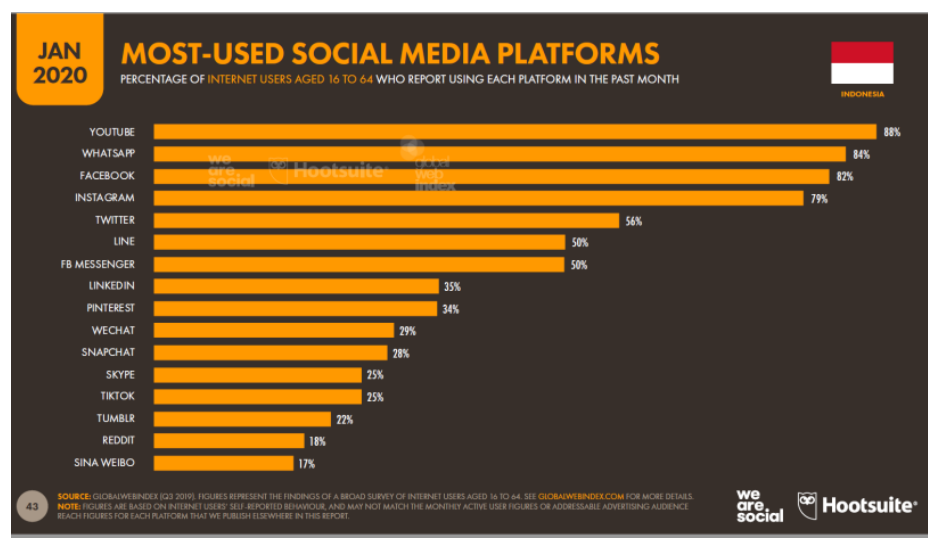

Sumber: (Digital 2020 (We Are Social))

Gambar 1. Most-Used Social Media Platforms

Beradasarkan survei dari APJII tahun 2020, sekitar 91,5\% orang menyatakan jika WhatsApp menjadi aplikasi perpesanan yang paling sering digunakan. Selain menjadi sarana bertukar pesan, WhatsApp juga dipilih oleh $93,7 \%$ orang Indonesia untuk melakukan video call (APJI, 2020).

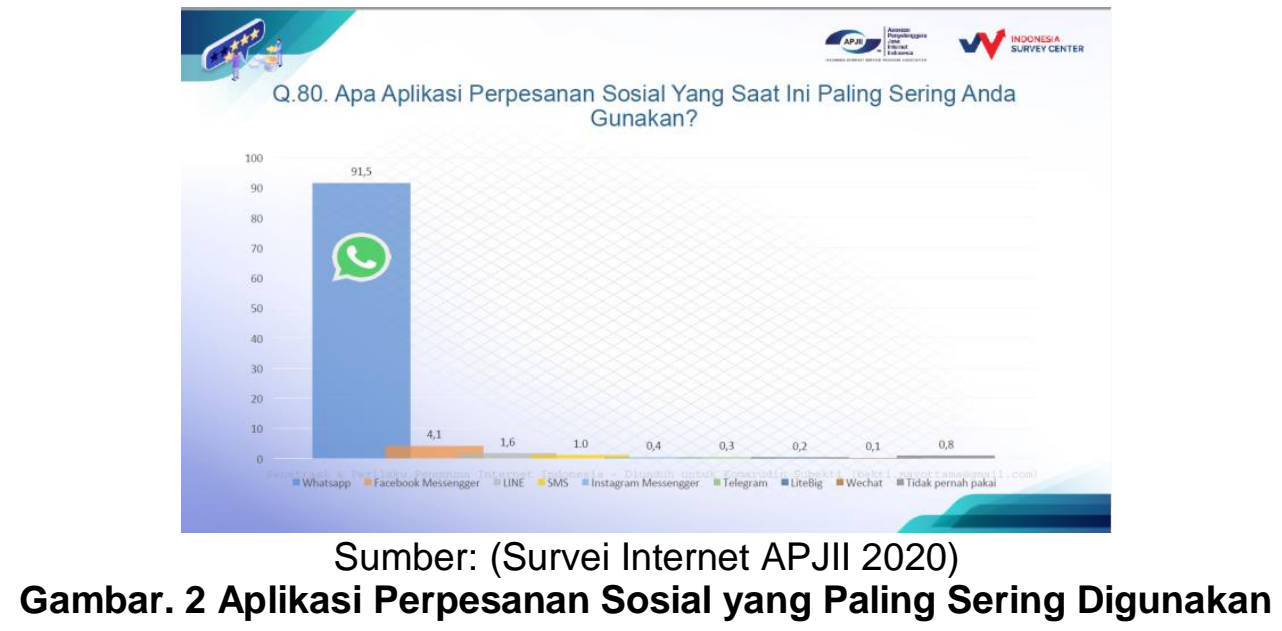

Di tengah pandemi COVID-19, yang membatasi jam kerja dan mewajibkan penurunan jumlah pegawai masuk di berbagai perusahaan dan instansi, termasuk instansi akademik, Fakultas Psikologi Universitas Pancasila sangat bergantung dengan aplikasi perpesanan WhatsApp sebagai salah satu media untuk berkomunikasi dan berkoordinasi terkait dengan berbagai macam pekerjaan. Grup percakapan WhatsApp bernama Civitas Academica Fakultas Psikologi Universitas Pancasila sebenarnya telah terbentuk sebelum ditetapkannya pandemi COVID-19. Fungsinya kurang lebih sebagai sebuah wadah komunikasi dan silaturahmi antar pimpinan, dosen, dan staf yang ada. Baik pimpinan hingga staf paling bawah memanfaatkan layanan grup percakapan tersebut dengan tujuan agar lebih mudah dan cepat dalam menyebarkan informasi, tanpa harus mengirimnya satu per satu kepada masing-masing pegawai, kecuali informasi yang bersifat rahasia. Dengan adanya grup percakapan WhatsApp, komunikasi antar pegawai dengan pimpinan juga dapat berlangsung lebih efektif. Grup percakapan yang ada tidak hanya ada satu, tetapi ada beberapa grup yang memang dikhususkan untuk koordinasi masing-masing bagian yang ada.

Komunikasi di dalam organisasi adalah suatu tindakan yang dilakukan oleh satu orang atau lebih yang berkomunikasi dengan cara mengirim, menginformasikan, menerima pesan, memberikan usulan, diskusi untuk menghasilkan sebuah umpan balik dalam menghasilkan pengertian dan tujuan yang sama. Wilbur Schramm mengemukakan bila komunikasi organisasi adalah sebuah proses berbagi (sharing process). Lebih lanjut, Schramm menyatakan jika 
komunikasi berasal dari bahasa Latin, yaitu communis yang berarti umum atau common, bisa juga berarti bersama. Dari hal tersebut, dapat kita ambil pemaknaan jika berkomunikasi artinya sedang menumbuhkan suatu kebersamaan (commons) dengan seseorang (Purnomo, 2018). Komunikasi organisasi sendiri berlangsung di dalam sebuah sistem terbuka yang kompleks dan dipengaruhi oleh lingkungannya sendiri, baik dari internal maupun eksternal yang mencakup pesan dan arusnya, tujuan, arah dan media, orang dan sikapnya, perasaannya, hubungannya dan keterampilannya (Badrudin et al., 2017).

Godhaber mengartikan komunikasi organisasi sebagai proses membuat dan bertukar pesan dalam jaringan hubungan yang saling bergantung untuk mengatasi ketidakpastian lingkungan (Badrudin et al., 2017). Unit komunikasi organisasi adalah hubungan antara orangorang dalam jabatan atau posisi dalam organisasi tersebut. Unit dasar dalam komunikasi organisasi yaitu seseorang dalam jabatan (Sedarmayanti, 2018).

Komunikasi di dalam sebuah organisasi merupakan sebuah tindakan yang dilakukan oleh satu orang atau lebih yang berkomunikasi dengan cara mengirim, menginformasikan, menerima pesan, memberikan usulan, diskusi untuk menghasilkan sebuah umpan balik dalam menghasilkan pengertian dan tujuan yang sama (Purnomo, 2018). Ada empat tujuan komunikasi organisasi, yaitu: (1) menyatukan pikiran, pandangan, dan pendapat, (2) membagi informasi, (3) menyatakan perasaan dan emosi, dan (4) melakukan koordinasi (Sedarmayanti, 2018).

Menurut Goldhaber (Atmaja \& Dewi, 2018), komunikasi organisasi membantu kita untuk (1) menyelesaikan tugas yang berkaitan dengan peran dan tanggung jawab khusus penjualan, layanan, dan produksi, (2) menyesuaikan diri dengan perubahan melalui kreativitas dan adaptasi individu dan organisasi, (3) menyelesaikan tugas melalui pemeliharaan kebijakan, prosedur, atau peraturan yang mendukung operasi harian dan berkelanjutan, (4) mengembangkan hubungan ketika pesan manusia diarahkan pada orang-orang di dalam organisasi sikap, moral, kepuasan, dan pemenuhan mereka.

Menurut Liliweri, (Sedarmayanti, 2018), terdapat dua fungsi komunikasi organisasi, yaitu: Fungsi umum komunikasi, berfungsi untuk: Menyampaikan/memberikan informasi kepada individu atau kelompok tentang bagaimana melaksanakan pekerjaan sesuai kompetensinya. Menjual gagasan dan ide, pendapat, dan fakta, termasuk menjual sikap organisasi dan sikap sesuatu yang merupakan subjek layanan. Meningkatkan kemampuan karyawan, agar mereka bisa belajar dari orang lain (internal), belajar tentang apa yang dipikirkan, dirasakan, dan dikerjakan orang lain tentang apa yang "dijual" atau yang diceritakan orang lain tentang organisasi. Menentukan apa dan bagaimana membagi pekerjaan atau siapa menjadi atasan dan menjadi bawahan, besaran kekuasaan dan kewenangan, serta menentukan bagaimana, memanfaatkan Sumber Daya manusia (SDM), dan mengalokasikan manusia, mesin, metode, dan teknik dalam organisasi. Fungsi Khusus komunikasi berfungsi untuk: Membuat karyawan melibatkan diri ke dalam isu organisasi lalu menerjemahkannya ke dalam tindakan tertentu di bawah sebuah perintah. Menciptakan dan menangani relasi antar sesama bagi peningkatan produk organisasi. Memiliki kemampuan menangani dan mengambil keputusan dalam suasana ambigu dan tidak pasti.

Menurut Sendjaja, (Jumrad \& Sari, 2019) di dalam organisasi komunikasi ada empat fungsi, yaitu :

\section{Fungsi Informatif}

Organisasi dilihat sebagai suatu sistem pemrosesan informasi (information processing system) di mana seluruh anggota organisasi berharap bisa memperoleh informasi yang lebih banyak, lebih baik dan tepat waktu. Dengan informasi yang didapatkan, anggota organisasi dapat melaksanakan pekerjaannya secara lebih pasti.

2. Fungsi Regulatif Fungsi regulatif berkaitan dengan peraturan-peraturan yang ada pada suatu organisasi. Pada semua organisasi terdapat dua hal yang berpengaruh kepada fungsi ini. Pertama, atasan (manajemen) yang punya kewenangan untuk mengendalikan seluruh informasi yang disampaikan. Kedua, terkait dengan pesan (message). Artinya, 
pesan-pesan yang bersifat regulatif pada dasarnya berorientasi pada kerja di mana bawahan memerlukan kepastian peraturan tentang pekerjaan yang boleh dan tidak boleh untuk dilaksanakan.

3. Fungsi Persuasif

Dalam mengatur organisasi, kekuasaan dan kewenangan tidak akan selalu membawa hasil sesuai dengan yang diharapkan. Oleh karena itu, banyak pimpinan lebih memilih mempersuasi bawahannya daripada memberi perintah, karena sebuah pekerjaan yang dilakukan secara sukarela akan menghasilkan kepedulian yang lebih besar dibandingkan ketika pimpinan memperlihatkan kekuasaan dan kewenangannya terhadap karyawan.

4. Fungsi Integratif

Setiap organisasi berusaha menyediakan saluran yang memungkinkan karyawan dapat menjalani tugas dan pekerjaan dengan baik. Ada dua saluran komunikasi yang dapat mewujudkan hal tersebut, yaitu saluran komunikasi formal, seperti penerbitan khusus dalam organisasi tersebut (newsletter, buletin) dan laporan kemajuan organisasi; juga saluran komunikasi informal, seperti perbincangan antar pribadi selama masa istirahat kerja, pertandingan olahraga atau kegiatan darmawisata.

\section{METODE PENELITIAN}

Dalam penelitian ini, penulis menggunakan pendekatan kualitatif dengan metode studi kasus pada grup percakapan WhatsApp Civitas Academica Fakultas Psikologi Universitas Pancasila. Menurut Moleong, penelitian kualitatif adalah penelitian yang bersifat interpretif atau memakai tafsiran yang menggunakan sudut pandang subjek pelaku penelitian. Metode yang digunakan dalam jenis penelitian ini biasanya menggunakan wawancara, pengamatan, maupun penggunaan dokumen. Penelitian deskriptif adalah penelitian yang dilakukan dengan mengumpulkan semua data kunci berupa kata-kata, gambar dan kutipan-kutipan data untuk memberikan gambaran penyajian laporan penelitian. Data-data tersebut dapat berasal dari naskah wawancara, kutipan lapangan, foto, videotape, dokumen pribadi catatan atau memo dan dokumen resmi lainnya. Selanjutnya dilakukan analisis data terhadap data-data tersebut dengan menelaah secara satu demi satu (Moleong, 2012).

Penelitian deskriptif juga dimaksudkan untuk melukiskan, menggambarkan, atau memaparkan keadaan objek (realitas atau fenomena) secara apa adanya, sesuai dengan situasi dan kondisi pada saat penelitian itu dilakukan. Manusia pada hakikatnya lebih banyak berkaitan dengan kualitas, yang oleh karenanya pendekatan kualitatif bersifat alamiah, kontekstual, mengutamakan perspektif, bersifat deskriptif, dan berorientasi proses, mengutamakan data langsung dan purposive, dengan analisis induktif yang berlangsung selama proses penelitian dimana peneliti berperan sebagai alat utamanya (Ibrahim, 2015).

Penelitian ini dilaksanakan pada bulan November 2020. Teknik pengumpulan data dilakukan dengan cara wawancara mendalam terhadap informan. Informan dipilih berdasarkan perwakilan dari anggota grup percakapan WhatsApp, yang terdiri dari pimpinan sebagai key informan, dosen tetap sebagai informan 1 dan informan 2, dan staf tenaga kependidikan (karyawan) sebagai informan 3 dan 4 yang seluruhnya tergabung di dalam grup percakapan WhatsApp Civitas Academica Fakultas Psikologi Universitas Pancasila.

\section{HASIL PENELITIAN DAN PEMBAHASAN}

Fakultas Psikologi Universitas Pancasila berdiri pada tanggal 7 Juni 2006 dengan Surat Keputusan Izin Operasional no 1884/D/T/2006 tanggal 7 Juni 2006 dan bernaung di bawah Yayasan Pendidikan Universitas Pancasila. Berdasarkan keputusan BPT No 4616/SK/BAN PT/Akred/S/XI/2019 November 2019, saat ini Program Studi Psikologi Terakreditasi dengan peringkat "A". Fakultas Psikologi Universitas Pancasila merupakan fakultas psikologi di Indonesia yang mengembangkan kurikulum psikologi bisnis sejak tahun 2012, kurikulum tersebut mengintegrasikan sejumlah bidang keilmuan antara lain psikologi industri dan 95 
organisasi, bisnis, ekonomi dan manajemen. Para mahasiswa tidak hanya dididik untuk memahami sifat dasar manusia, tetapi memperoleh pembekalan beragam pengetahuan mengenai proses bisnis sebuah organisasi.

Dalam mewujudkan institusi pendidikan yang efektif dan dan efisien manajemen dan civitas academica di Fakultas Psikologi Universitas Pancasila melaksanakan Good Faculty Governance. Secara sederhana dapat diartikan sebagai suatu semangat pengelolaan fakultas yang bersih, sehat, transparan, akuntabel, bertanggung jawab, independen, jujur dan adil dalam upaya menciptakan academic excellence dan kinerja organisasi yang tumbuh dan berkembang secara berkesinambungan. Pertumbuhan kinerja yang berkesinambungan sangatlah penting dalam meningkatkan mutu akademik dan non akademik yang bermuara pada mutu lulusan fakultas psikologi. Dalam upaya untuk mencapai hal tersebut, maka ditetapkan kebijakan akademik dan rencana strategis yang memperhatikan kebutuhan para pemangku kepentingan (Stakeholders). Dengan menerapkan sistem link and match maka diharapkan para pengguna lulusan dapat memberikan masukan atau kritik terhadap proses belajar mengajar di Fakultas Psikologi Universitas Pancasila. Dengan demikian maka mutu akademik dapat ditingkatkan dari waktu ke waktu sesuai dengan kebutuhan masyarakat.

Visi Fakultas Psikologi Universitas Pancasila adalah "Pada tahun 2027, menjadi Fakultas Psikologi bermutu internasional, dengan fokus pengembangan keilmuan dan kompetensi Psikologi yang menyumbang pada kesejahteraan manusia berdasarkan nilai-nilai luhur Pancasila."

Misi Fakultas Psikologi Universitas Pancasila sendiri adalah :

1) Menyelenggarakan proses pendidikan tinggi psikologi yang berorientasi pada peningkatan kesejahteraan manusia yang memenuhi standar internasional.

2) Mengembangkan penelitian dan publikasi ilmiah psikologi yang memenuhi standar internasional.

3) Mengembangkan program pengabdian kepada masyarakat yang berkesinambungan serta memberi dampak bagi peningkatan kesejahteraan manusia.

4) Menerapkan tata kelola Fakultas yang profesional berdasarkan prinsip Good University Governance.

5) Menyelenggarakan kegiatan pengembangan kemahasiswaan dan alumni yang mendukung terbentuknya kompetensi psikologi sebagai modal dasar dalam berkontribusi untuk meningkatkan kesejahteraan manusia.

Fakultas Psikologi Universitas Pancasila memiliki jumlah SDM sebanyak 35 orang, yang terbagi antara dosen dan tenaga kependidikan. Jumlah dosen tetap yang dimiliki sebanyak 17 orang sedangkan untuk dosen tidak tetap sendiri jumlahnya menyesuaikan tiap semesternya, tergantung kebutuhan. Dalam satu semester, dosen tidak tetap yang mengajar maksimal 8 orang saja. Dari 17 orang dosen tetap yang ada, sebanyak 6 orang sedang menempuh pendidikan Strata 3. Untuk tenaga kependidikan atau karyawan berjumlah 18 orang yang terdiri dari 5 orang karyawan tetap, 13 orang karyawan kontrak, dan 1 karyawan purnabakti.

Adapun latar belakang pendidikan SDM di Fakultas Psikologi Universitas Pancasila, yaitu Strata 3 (S3) sebanyak 4 orang, Strata 2 (S2) sebanyak 14 orang, Strata 1 (S1) sebanyak 7 orang, Diploma (D3) sebanyak 1 orang, dan SMA sebanyak 4 orang. Latar pendidikan S2 menjadi terbanyak karena mayoritas dosen di Fakultas Psikologi Universitas Pancasila harus memiliki pendidikan minimal S2.

Saat ini, Fakultas Psikologi Universitas Pancasila sendiri memiliki kurang lebih 5 grup percakapan WhatsApp yang terdiri dari grup pimpinan fakultas, grup civitas academica (tidak termasuk dosen tidak tetap), grup dosen (di dalamnya termasuk juga dosen tidak tetap), grup bidang 1 (Akademik, Kemahasiswaan, dan Alumni), dan grup bidang 2 (Administrasi, Umum, Keuangan, dan Aset). Tujuan utama pembuatan grup adalah untuk memudahkan komunikasi, instruksi, pelaporan pekerjaan, dan penyebaran informasi di kalangan pegawai di lingkungan Fakultas Psikologi Universitas Pancasila. Dalam penelitian ini, penulis fokus pada grup 
percakapan WhatsApp Civitas Academica Fakultas Psikologi Universitas Pancasila. Ada sekitar 32 orang yang tergabung di dalam grup tersebut.

Hasil dari observasi dan wawancara yang telah dilakukan oleh penulis terhadap subjek penelitian, didapatkan data dan informasi yang akan dijelaskan di dalam hasil penelitian. Hasil penelitian yang ada kemudian diuraikan sesuai dengan unit analisis yang telah ditentukan sebelumnya. Unit analisis yang digunakan yaitu, fungsi komunikasi dalam organisasi dan masing-masing indikator yang mendukung. Hasil penelitian Fungsi Komunikasi dalam Organisasi Melalui Grup Chat WhatsApp Fakultas Psikologi Universitas Pancasila menggunakan teori yang dikemukakan oleh Sendjaja (Jumrad \& Sari, 2019) adalah:

Fungsi informatif, organisasi dilihat sebagai suatu sistem pemrosesan informasi (information processing system) di mana seluruh anggota organisasi berharap bisa memperoleh informasi yang lebih banyak, lebih baik dan tepat waktu. Lewat informasi yang diperoleh, seluruh anggota organisasi mendapatkan instruksi pekerjaan yang lebih pasti. Fungsi komunikasi organisasi sebagai fungsi informatif di dalam grup percakapan WhastApp Civitas Academica Fakultas Psikologi Universitas Pancasila bagi pimpinan, di antaranya adalah menyampaikan informasi atau instruksi pekerjaan. Lewat informasi atau instruksi yang disampaikan, pimpinan berharap agar pekerjaan dapat terselesaikan dengan cepat tanpa ada halangan. Sebaliknya, bagi para dosen dan staf tenaga kependidikan sebagai komunikan, mereka bisa mendapatkan informasi dan instruksi pekerjaan untuk membantu dalam menjalankan serta menyelesaikan tugas-tugas yang ada.

Fungsi regulatif berkaitan dengan peraturan-peraturan yang ada pada suatu organisasi. Pada semua organisasi terdapat dua hal yang berpengaruh kepada fungsi ini. Pertama, atasan (manajemen) yang punya kewenangan untuk mengendalikan seluruh informasi yang disampaikan. Kedua, terkait dengan pesan (message). Artinya, pesan-pesan yang bersifat regulatif pada dasarnya berorientasi pada kerja di mana bawahan memerlukan kepastian peraturan tentang pekerjaan yang boleh dan tidak boleh untuk dilaksanakan. Fungsi komunikasi organisasi sebagai fungsi regulatif di dalam grup percakapan WhastApp Civitas Academica Fakultas Psikologi Universitas Pancasila berorientasi pada kerja atau hal yang harus dipahami oleh setiap anggota, baik itu aturan pada saat berada di dalam grup dan aturan dalam melaksanakan pekerjaan. Aturan ini tentunya memberikan gambaran kepada setiap anggota agar lebih mudah mengerjakan pekerjaannya sesuai dengan aturan-aturan berlaku. Karena pada dasarnya, informasi terkait pekerjaan di dalam grup percakapan WhatsApp bersifat sangat rahasia.

Fungsi persuasif, dalam mengatur organisasi, kekuasaan dan kewenangan tidak akan selalu membawa hasil sesuai dengan yang diharapkan. Oleh karena itu, banyak pimpinan lebih memilih mempersuasi bawahannya daripada memberi perintah, karena sebuah pekerjaan yang dilakukan secara sukarela akan menghasilkan kepedulian yang lebih besar dibanding ketika pimpinan memperlihatkan kekuasaan dan kewenangannya terhadap karyawan. Fungsi komunikasi organisasi sebagai fungsi persuasif yang dilakukan di dalam grup percakapan WhastApp Civitas Academica Fakultas Psikologi Universitas Pancasila oleh pimpinan sebagai komunikator yang melakukan persuasi kepada para bawahan untuk menjalankan tugas-tugas yang diberikan serta membuat laporan dari tugas-tugas tersebut.

Fungsi integratif, setiap organisasi berusaha menyediakan saluran yang memungkinkan karyawan dapat menjalani tugas dan pekerjaan dengan baik. Ada dua saluran komunikasi yang dapat mewujudkan hal tersebut, yaitu saluran komunikasi formal, seperti penerbitan khusus dalam organisasi tersebut (newsletter, buletin) dan laporan kemajuan organisasi; juga saluran komunikasi informal, seperti perbincangan antar pribadi selama masa istirahat kerja, pertandingan olahraga atau kegiatan darmawisata. Fungsi komunikasi organisasi sebagai fungsi integratif yang dilakukan di dalam grup percakapan WhastApp Civitas Academica Fakultas Psikologi Universitas Pancasila salah satunya adalah dengan adanya beberapa grup percakapan ini. Lewat adanya grup percakapan WhatsApp, penyebaran informasi di dalam organisasi dirasa telah cukup. 
Penelitian ini berupaya mengungkapkan fungsi komunikasi organisasi melalui grup percakapan WhatsApp Fakultas Psikologi Universitas Pancasila. Berdasarkan analisis fungsi komunikasi organisasi, terlihat bahwa fungsi komunikasi organisasi melalui grup percakapan WhatsApp Civitas Academica Fakultas Psikologi Universitas Pancasila telah berjalan cukup baik.

Pada fungsi komunikasi organisasi terdapat beberapa konten atau isi pada grup percakapan WhatsApp Civitas Academica Fakultas Psikologi Universitas Pancasila, yaitu (1) informasi, (2) perintah kerja, (3) berita, dan (4) obrolan atau percakapan. Keempat konten ini mengisi seluruh grup percakapan Fakultas Psikologi Universitas Pancasila, baik grup dosen, masing-masing bidang, dan grup civitas academica Fakultas Psikologi Universitas Pancasila.

Fungsi pertama, fungsi informatif sejalan dengan teori yang dijelaskan oleh Barker (Soedarsono, 2009; 34-35) (Widjajanto, 2013: 6) yang menyatakan bila fungsi informatif antara pimpinan dan karyawan dalam organisasi sangat membutuhkan informasi yang diterima dan berfungsi efisien dan teori yang diungkapkan oleh Sendjaja (Jumrad \& Sari, 2019) Organisasi dilihat sebagai suatu sistem pemrosesan informasi (information processing system) di mana seluruh anggota organisasi berharap bisa memperoleh informasi yang lebih banyak, lebih baik dan tepat waktu. Dengan informasi yang didapatkan, anggota organisasi dapat melaksanakan pekerjaannya secara lebih pasti.

Fungsi komunikasi organisasi sebagai fungsi informatif dalam obrolan grup WhatsApp Civitas Academica Fakultas Psikologi Universitas Pancasila membuat pesan-pesan informatif yang disampaikan oleh anggota grup, khususnya para pimpinan, agar dapat membantu para anggota yang lainnya agar dapat melakukan pekerjaan lebih terarah. Informasi yang disampaikan dengan serentak dan merata, juga lebih efisien lewat penyampaiannya yang cepat. Diharapkan para SDM Fakultas Psikologi Universitas Pancasila dapat menerima informasi tepat waktu agar dapat bekerja dengan baik sesuai informasi yang didapatkan.

Fungsi informatif, komunikasi melalui group percakapan WhatsApp yang digunakan oleh anggota grup, terutama pimpinan sebagai langkah untuk menyediakan informasi yang terbuka dan cukup seputar Fakultas Psikologi Universitas Pancasila. Proses dan penyebaran informasi dalam group percakapa WhatsApp, selalu diupayakan agar setiap informasinya dapat diterima dan disebarkan sesegera mungkin, baik kepada anggota grup lainnya, mahasiswa, maupun orang lain di luar civitas academica Fakultas Psikologi Universitas Pancasila.

Komunikasi melalui grup percakapan WhatsApp yang digunakan Fakultas Psikologi Universitas Pancasila bermaksud untuk menyediakan informasi yang terbuka dan cukup seputar pekerjaan dan tanggung jawab para dosen serta tenaga kependidikan. Grup percakapan WhatsApp Civitas Academica Fakultas Psikologi Universitas Pancasila juga memberikan ruang untuk dapat berkomunikasi, baik itu secara komunikasi vertikal, horizontal, linier, ataupun Komunikasi juga tidak dilakukan hanya satu arah saja, melainkan semua pegawai yang ada di dalam grup tersebut dapat melakukan komunikasi. Salah satu contoh komunikasi dalam lingkup fungsi informatif di dalam grup percakapan WhatsApp Civitas Academica Fakultas Psikologi Universitas Pancasila adalah : 


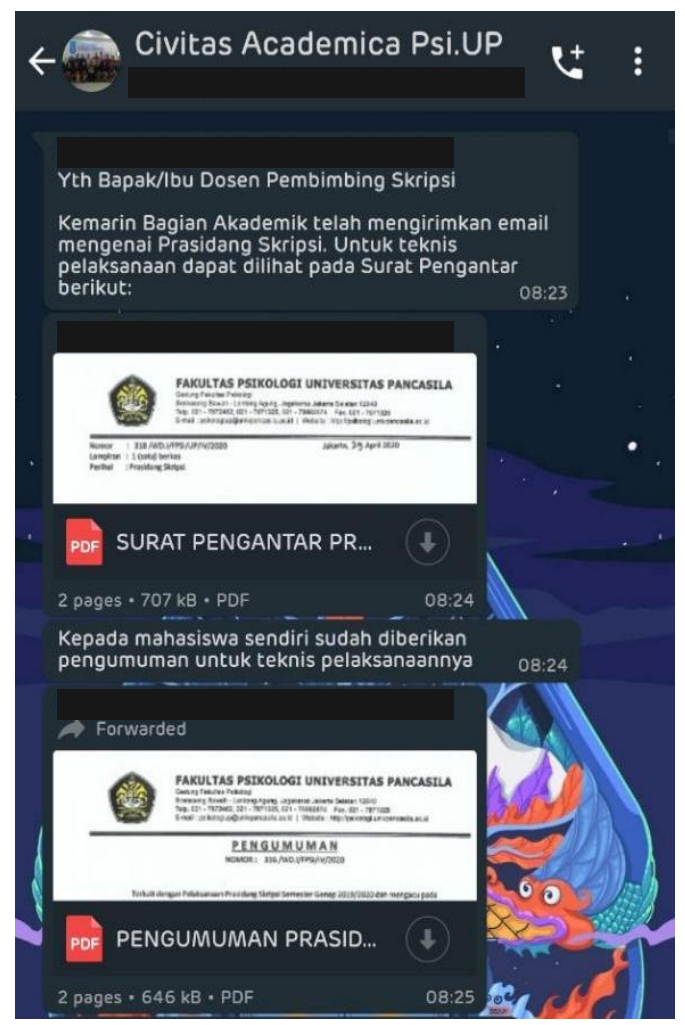

(Sumber : Dok. Pribadi)

\section{Gambar 3. Komunikasi dalam Lingkup Fungsi Informatif: Penyebaran Surat dan Pengumuman}

Dari hasil wawancara dengan key informan dijelaskan:

"WhatsApp merupakan salah satu teknologi komunikasi yang cukup canggih dan kuat. Lewat WhatsApp, komunikasi bisa berjalan ke segala arah, tidak hanya satu arah saja. Dari atas ke bawah, bawah ke atas, saling silang, pokoknya sebuah terobosan yang sangat canggih."

Dari pernyataan tersebut kita dapat menarik kesimpulan jika grup percakapan WhatsApp Civitas Academica Fakultas Psikologi Universitas Pancasila memiliki akses komunikasi yang tidak terikat dengan tingkatan jabatan. Komunikasi yang dilakukan juga tidak terbatas hanya satu arah saja, tetapi juga dua arah dan masing-masing anggota dapat dengan leluasa menyampaikan informasi. mengatakan:

Sama seperti key informan, informan 4 juga menyatakan hal yang senada. Informan 4

"Grup WhatsApp sangat informatif, apalagi di masa pandemi seperti ini. Informasi bisa disampaikan langsung ke semua yang berkepentingan tanpa harus menunggu atau mencari tahu. Mulai dari pengumuman, undangan, atau berita lainnya bisa diakses dengan mudah." berpendapat:

Namun, berbeda dengan pernyataan key informan dan informan 4, informan 2

"Memang informatif, tetapi kita juga harus tetap cross check ke pimpinan lagi. Karena kalau di WhatsApp kan sifatnya hanya memberitahukan sekilas saja, detail dan lainnya harus kita konfirmasikan lagi dengan si pemberi informasi, misalnya."

Berbeda lagi dengan informan 1 yang menyampaikan:

"Sebenarnya WhatsApp ini belum ada dasarnya ya, kalau mau aman ya tentunya mengikuti peraturan yang sudah jelas dasarnya. Kasih surat, disposisinya jelas, pemberitahuan 
resmi, dan lain-lainnya begitu. WhatsApp hanya untuk mempercepat penyebaran informasi saja, tidak resmi."

Lebih lanjut, key informan juga menjelaskan jika fungsi grup percakapan WhatsApp memang sebagai salah satu kanal informasi saja. Dia mengatakan:

"Grup WhatsApp sebenarnya untuk informasi saja, perkara penyelesaian pekerjaan ya itu nanti masing-masing pegawai harus laporan ke pimpinan atau atasan langsung. Informasi yang disebar di grup WhatsApp fungsinya untuk mengingatkan. Hanya direspon dengan kata OK atau tidak dijawab sama sekali juga tidak apa-apa. Yang penting paham dengan apa yang diperintahkan, laporannya juga harus jelas."

Dari penjelasan tersebut, dapat diambil kesimpulan jika grup percakapan WhatsApp Civitas Academica Fakultas Psikologi Universitas Pancasila digunakan sebagai sarana penyebaran informasi saja. Hal ini karena lapora pekerjaan para pegawai harus dibuat dan dikirimkan secara resmi kepada pimpinan atau atasan langsung.

Fungsi informatif di dalam grup percakapan WhatsApp Civitas Academica Fakultas Psikologi Universitas Pancasila telah berjalan dengan normal, tetapi masih ada yang beranggapan bila WhatsApp bukanlah media resmi untuk penyampaian informasi dan pesan. Penyampaian informasi dan pesan menurut salah satu iforman tetap harus secara resmi. Akan tetapi, WhatsApp mempermudah aliran informasi di dalam lingkungan Fakultas Psikologi Universitas Pancasila. Informasi disebarkan secara informal kepada seluruh anggota grup Civitas Academica Fakultas Psikologi Universitas Pancasila, meskipun tetap harus melakukan cross check kepada atasan atau pimpinan.

Alvanco (2014) menyatakan bahwa fungsi regulatif adanya komunikasi memungkinkan setiap orang dalam organisasi, memiliki kejelasan aturan main, tugas, tanggung jawab serta wewenangnya. Perintah lewat surat atau disposisi resmi secara regulatif memang lebih formal dibandingkan bila menggunakan grup percakapan WhatsApp, meskipun akses ke grup percakapan lebih mudah dan lebih cepat. Pada dasarnya, perintah kerja yang diinstruksikan lewat grup percakapan WhatsApp lebih kepada instruksi untuk mengerjakan sesuatu. Proses penyelesaian dan pelaporan pekerjaannya nantinya tetap akan dilakukan secara tertulis dan resmi.

Fungsi regulatif pada penelitian ini difokuskan pada pesan-pesan komunikasi yang bersifat regulatif yang disampaikan oleh pimpinan (bisa lewat sekretaris atau kepala bagian) yang pada dasarnya berorientasi pada aturan yang berlaku dan tanggung jawab pekerjaan yang diemban. Aturan yang dimaksud dalam grup obrolam WhatsApp Civitas Academica Fakultas Psikologi Universitas Pancasila, seperti penyosialisasian aturan atau regulasi-regulasi baru di dalam pekerjaan. Sosialisasi aturan di dalam grup percakapan memang hanya sebatas pemberitahuan saja karena selanjutnya akan dibahas di dalam forum atau rapat koordinasi yang diadakan setiap satu minggu sekali. Salah satu contoh komunikasi dalam lingkup fungsi regulatif di dalam grup percakapan WhatsApp Civitas Academica Fakultas Psikologi Universitas Pancasila adalah :

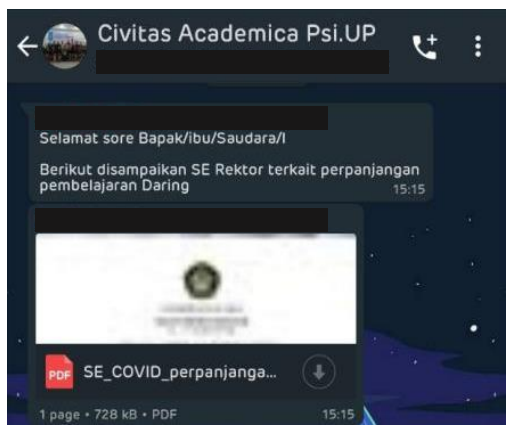

Sumber : Dok. Pribadi

Gambar 4. Komunikasi dalam Lingkup Fungsi Regulatif: Pendistribusian Surat Edaran dari Rektor 
Fungsi regulatif, dalam group percakapan WhatsApp Civitas Academica Fakultas Psikologi Universitas Pancasila, komunikasi dianggap sebagai media pembawa pesan-pesan yang berkaitan dengan peraturan dalam menjalankan pekerjaan. Pesan-pesan tersebut kemudian disampaikan secara langsung oleh pimpinan atau lewat Kasubag dan Kabag, bisa juga oleh skretaris dekan untuk kemudian diteruskan kepada dosen atau pegawai lainnya. Aturan-aturan yang dimaksud seperti surat keputusan rektor atau dekan, perubahan atau arahan baru dari rektor atau dekan, dan lain-lainnya.

Key informan berpendapat jika:

"WhatsApp sebenarnya memang untuk komunikasi informal. Mau formal ya kita ada email. Seminggu sekali juga ada yang namanya rapat koordinasi. Jadi WhatsApp singkatnya untuk memberitahu saja. Lebih lanjut dan detail ada di email atau pas rapat nanti dibahas.

Masih dengan pendapatnya yang sebelumnya, informan 1 menyampaikan :

"Iya, memang informal. Di WhatsApp biasanya pimpinan hanya memberikan informasi terbatas, seperti memanggil dosen atau karyawan, selanjutnya nanti yang bersangkutan akan menghadap. Isi pesan yang ada di di dalam grup percakapan sebatas arahan saja sedangkan untuk report pekerjaan bisa dengan langsung melaporkannya ke pimpinan terkait."

Email resmi dari fakultas masih menjadi media formal dalam menyampaikan pesan. Meskipun lebih cepat diakses oleh seluruh pegawai, tetapi isi dari pesan dan informasi yang ada di grup percakapan Whatsapp kebanyakan adalah arahan untuk melakukan atau mengerjakan sesuatu, sedangkan pada email dan rapat mingguan biasanya merupakan disposisi perintah untuk menyelesaikan pekerjaan.

Key Informan menambahkan :

"Sebenarnya tidak ada masalah bila mau berkomunikasi lewat grup WhatsApp, apalagi keadaannya sedang seperti ini, tidak boleh kumpul-kumpul. Yang penting apa yang dikerjakan selalu di-update kepada pimpinan, bisa ke langsung ke dekan atau para wakilnya sebagai bentuk laporan."

Penggunaan grup percakapan WhatsApp meskipun dianggap informal, tetapi merupakan sarana penyampaian pesan yang cepat. Penyampaian pesan melalui grup percakapan WhatsApp wajib untuk dicek kembali melalui surat tugas yang dianggap formal, dan meminta arahan lebih lanjut kepada Wakil Dekan masing-masing bidang, sebagai bagian dari konfirmasi, apakah sudah sesuai dengan apa yang dikerjakan dengan apa yang menjadi instruksi dari pimpinan.

Menurut Badrudin (2017) Fungsi persuasif lebih banyak dimanfaatkan oleh pihak pimpinan dalam sebuah organisasi dengan tujuan untuk memperoleh dukungan dari karyawan. Fungsi persuasif adalah penyeimbang dari pemberian instruksi. Seorang atasan harus pintarpintar mendapatkan hati para karyawan, maka persuasif inilah caranya. Atasan dalam memberikan instruksi pekerjaan juga harus dibarengi dengan sikap mengajak yang santun dan bijak. Sebab pekerjaan yang dilakukan secara sukarela oleh karyawan akan menghasilkan kepedulian yang lebih besar dibanding jika pimpinan sering memperlihatkan kekuasaan dan kewenangan.

Fungsi persuasif lebih banyak dimanfaatkan oleh pimpinan untuk memperoleh dukungan dari dosen atau karyawan. Fungsi persuasif merupakan penyeimbang dari pemberian intruksi. Pimpinan semestinya harus bisa mendapatkan hati para bawahannya, maka teknik persuasif ini sebagai salah satu caranya. Di dalam memberikan intruksi pekerjaan, seorang pimpinan atau atasan juga harus dibarengi dengan sikap mengajak yang santun dan bijak. Pekerjaan yang dilakukan secara sukarela oleh para bawahan tentunyua akan menghasilkan kepedulian yang lebih besar dibanding jika pimpinan sering memperlihatkan kekuasaan dan kewenanganya. Komunikasi persuasif yang dilakukan oleh pimpinan Fakultas Psikologi Universitas Pancasila dalam group percakapan WhatsApp lebih kearah mengajak para anggota dalam membuat sesuatu, seperti video perayaan atau ucapan selamat. Salah 
satu contoh komunikasi dalam lingkup fungsi persuasif di dalam grup percakapan WhatsApp Civitas Academica Fakultas Psikologi Universitas Pancasila adalah :

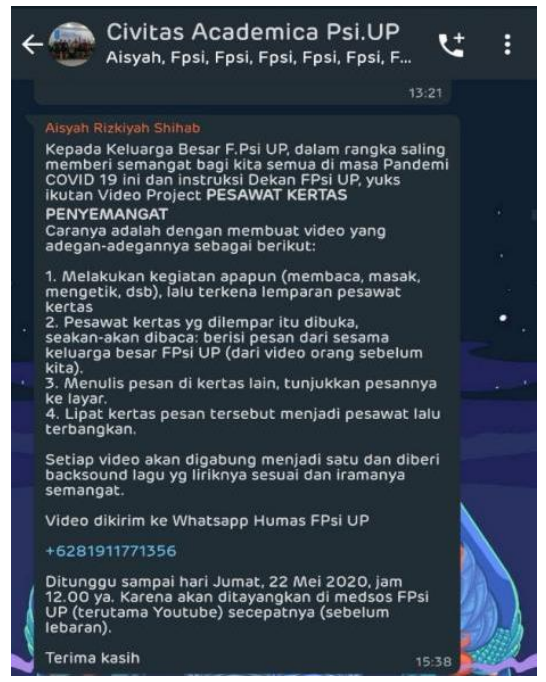

Sumber: Dok. Pribadi

\section{Gambar 5. Komunikasi dalam Lingkup Fungsi Persuasif: Imbauan untuk Membuat Video Penyemangat}

Menurut Devito (Jumrad \& Sari, 2019) strategi untuk merangsang pendengar bertindak dalam pembicaraan secara persuasif dalam mempersuasi seseorang ia harus menunjukan ketersediaannya untuk melakukan hal yang sama, dan memperlihatkan kepada mereka bahwa Anda senang melakukannya, selanjutnya tunjukan manfaat spesifik dari perilaku yang dilakukan kepada khalayak anda, karena dalam strategi merangsang seseorang untuk melakukan tindakan seperti yang kita harapkan kita jangan meminta khalayak untuk menjalankan sesuatu perilaku karena alasan-alasan yang tidak jelas, berikan mereka contoh konkret dan spesifik mengenai bagaimana mereka akan mendapatkan manfaat dari tindakan yang anda ingin mereka lakukan.

Informan 1 menjelaskan jika tidak bisa dengan menggunakan grup percapakan WhatsApp saja, tetapi juga memakai cara yang lain seperti 'Jaringan Pribadi' (Japri) WhatsApp dalam memberikan instruksi atau arahan kepada bawahan langsung. Beliau menambahkan:

"Paling penting, suasananya dulu. Kita juga harus bangun keakraban di dalam grup supaya memberikan arahan juga lebih enak dan tujuan bersama bisa tercapai. Komunikasi yang menjadi kuncinya, mau itu surat tugas, kepanitiaan, atau ucapan selamat kalau hanya dibagikan saja tanpa ditanggapi kan juga bikin kita tidak nyaman. Membagikan dengan cara yang salah juga ujungnya bisa fatal. Makanya, bila ada yang dirasa confidential atau sangat rahasia lebih baik menggunakan jalur pribadi saja"

Informan 4 mengatakan:

"Dalam memberikan pekerjaan secara langsung, tentunya bahasa yang digunakan oleh pimpinan harus persuasif yang tidak cenderung ke otoriter, seperti main perintah saja. Mau itu persuasif atau arahan, ya tetap kita harus mematuhi perintah pimpinan."

Fungsi persuasif juga merupakan pemberian instruksi tidak hanya menggunakan grup percakapan WhatsApp saja, melainkan juga menggunakan sarana yang lain, seperti jalur pribadi (japri) WhatsApp atau arahan kepada subordinat di bawahnya. Dosen dan tenaga kependidikan sangat perlu mengetahui tugas dan fungsi organisasi serta pribadi agar mereka dapat bertanggung jawab di dalam mengerjakan fungsi dan tugas yang diberikan. Pada grup percakapan WhatsApp Civitas Academica Fakultas Psikologi Universitas Pancasila yang bertanggung jawab dalam memberikan arahan adalah Dekan serta Wakil Dekan 1 dan 2 
kepada para bawahannya untuk dapat dilaksanakan. Arahan itu bersifat persuasif, bukan dalam bentuk otoriter, sehingga dapat bertukar pikiran dan menerima masukkan/saran pada grup percakapan tersebut.

Dalam menjalankan fungsi komunikasi organisasi, secara informatif, regulatif, dan persuasif dibutuhkan sebuah saluran komunkasi yang tepat untuk menyampaikan 3 fungsi tersebut. Seperti yang dilakukan oleh Fakultas Psikologi Universitas Pancasila dalam mengaplikasikan komunikasi organisasi dalam fungsi integratif adalah dengan menyediakan saluran yang memungkinkan pegawai bisa menjalankan tugas dengan baik. Selain grup percakapan WhatsApp, tersedia pula surat elektronik (email) yang dapat digunakan oleh para pegawai untuk berkomunikasi secara formal. Dalam berkomunikasi informal, pegawai bisa menggunakan jalur pribadi lewat berbagai aplikasi obrolan yang ada. Sesekali, obrolan informal juga terjadi dalam grup percakapan WhatsApp Civitas Academica Fakultas Psikologi Universitas Pancasila, seperti berikut ini contohnya:

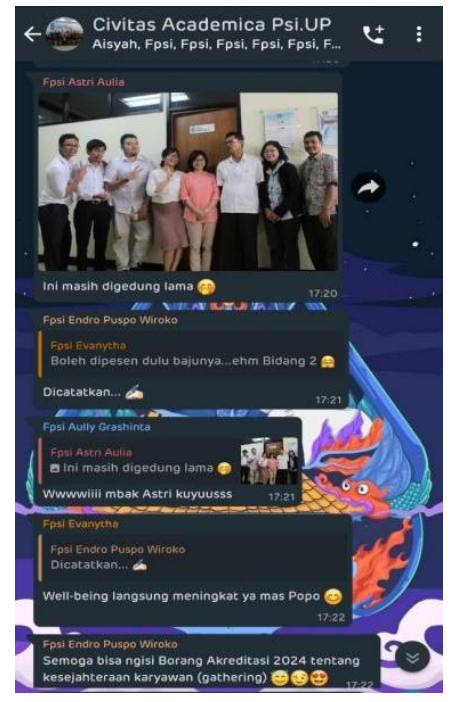

Sumber : Dok. Pribadi

\section{Gambar 5. Komunikasi dalam Lingkup Fungsi Integratif: Percakapan Antar Pegawai}

Daryanto (2011) menyatakan bahwa saluran komunikasi adalah jalan yang dilalui pesan komunikator untuk sampai ke komunikannya. Terdapat 2 jalan agar pesan komunikasi sampai ke komunikannya yaitu tanpa media yang berlangsung face to face, tatap muka atau dengan media. Media disini adalah media komunikasi diartikan sebagai alat perantara yang pilih komunikator dengan sengaja untuk menghantarkan pesannya untuk sampai ke komunikan. Jadi unsur utama dari media komunikasi adalah pemilihan dan penggunaan alat yang dilakukan komunikator dengan sengaja. Artinya hal ini mengacu kepada pemilihan dan penggunaan teknologi media komunikasi. Dalam penelitian ini, pimpinan organisasi memilih salah satu saluran komunikasi sebagai alat penyampaian informasi melalui grup percakapan WhatsApp untuk mengkomunikasikan tentang pekerjaan baik informasi secara formal maupun informal kepada para bawahannya.

Pada penelitian ini, yang dipilih sebagai saluran komunikasi untuk menyampaikan informasi adalah grup percakapan WhatsApp. Informasi yang disampaikan baik tentang pekerjaan secara formal maupun informal kepada seluruh anggota grup yang terdiri dari dosen dan pegawai atau tenaga kependidikan. Pemilihan WhatsApp sebagai saluran komunkasi dipilih secara sengaja sebagai media penyampaian informasi karena media tersebut sangat memenuhi kebutuhan komunkasinya dalam menyampaikan informasi tentang pekerjaan dan dapat selalu terhubung dengan para anggota grup selama 24 jam. 
Informan 4 berpendapat :

"Memang sekarang kebanyakan komunikasi di grup, tetapi kami juga masih menggunakan email untuk berkomunikasi masalah pekerjaan. Hasil rapat daring misalnya, dikirimnya ya via email. Jadi semuanya bisa tercatat rapi dan terlihat historinya."

Sementara itu, informan 3 memiliki pandangan sebagai berikut:

"Grup WhatsApp ini ya untuk menyatukan semuanya, meskipun masing-masing bagian juga punya grup sendiri, tapi di grup besar ini semuanya kumpul dan saling berbagai informasi."

Selain saluran Informasi melaui grup percakapan WhatsApp dan email, Fakultas Psikologi Universitas Pancasila juga menyediakan saluran informasi lainnya, yaitu website dan sosial media. Penggunaan fungsi integratif telah mulai dilakukan dengan selalu memperhatikan penyimpanan data, misalnya melalui email agar dapat diakses dan penyimpanannya lebih lama. Penyatuan semua yang terlibat dalam grup percakapan WhatsApp juga sudah terjadi.

\section{SIMPULAN}

Berdasarkan analisis fungsi komunikasi dalam organisasi melalui grup percakapan WhatsApp Civitas Academica Fakultas Psikologi Universitas Pancasila ditemukan bahwa fungsi komunikasi organisasi dalam grup percakapan WhatsApp terdiri dari fungsi informatif, fungsi regulatif, fungsi persuasif dan fungsi integratif. Grup percakapan WhatsApp menjadi sarana untuk mempercepat arus informasi. Partisipasi aktif seluruh anggota grup sangat diharapkan, meskipun WhatsApp bukanlah forum resmi dan tidak memiliki dasar pengaturan jelas di dalam Fakultas Psikologi Universitas Pancasila.

Grup percakapan WhatsApp Civitas Academica Fakultas Psikologi Universitas Pancasila memberikan informasi cukup yang dibutuhkan pegawai untuk mengerjakan tugas, walaupun belum dapat dijadikan landasan dalam bekerja karena sifatnya yang informal. Grup percakapan Civitas Academica Fakultas Psikologi Universitas Pancasila juga membutuhkan pengecekan data ke sekretaris dekan atau ke kepala bagian serta meminta arahan lebih lanjut kepada Dekan Fakultas Psikologi Universitas Pancasila sebagai bagian dari konfirmasi apakah telah sesuai dengan apa yang menjadi instruksi pimpinan.

Rekomendasi yang dapat diusulkan adalah membuat dasar hukum yang jelas terkait media komunikasi grup percakapan WhatsApp atau membuat aplikasi percakapan resmi yang khusus digunakan oleh pegawai di lingkungan Fakultas Psikologi Universitas Pancasila, dan Universitas Pancasila secara umum. Dalam penelitian selanjutnya, disarankan agar dapat meneliti tentang strategi komunikasi organisasi di dalam menjalankan pekerjaan sesuai dengan tujuan organisasinya.

\section{DAFTAR PUSTAKA}

Alvanco, J. (2014). Pratical Communication Skill. Jakarta: Elex Media Komputindo.

Atmaja, S., \& Dewi, R. (2018). Komunikasi Organisasi (Suatu Tinjauan Teoritis Dan Praktis). Inter Komunika Jurnal Komunikasi, 3(2), 192-206.

Badrudin, S. (2017). Analisis Komunikasi Organisasi di Pusat Informasi Haji Kantor Wilayah Kementerian Agama Provinsi Sumatera Selatan. Jurnal Komunikasi Islam dan Kehumasan, 1(1), 14.

Bala, Kiran. (2014). Social Media And Changing Communication Patterns. Global Media Journal-Indian Edition, 5(01), 4.

Barokah, D. R. (2019). Kominfo: 83\% Pengguna Internet adalah Pengguna Whatsapp. Dipetik Februari 2021. https://www.gatra.com/detail/news/457263/teknologi/kominfo-83pengguna-internet-adalah-pengguna-whatsapp\#

Daryanto. (2011). IImu Komunikasi. Bandung: Sarana Tutorial Nurani Sejahtera.

Fakultas Psikologi Universitas Pancasila. (2019). Dipetik November 2020, dari Sejarah: http://psikologi.univpancasila.ac.id 
Hermawan, C. W. (2009). Cara Mudah Membuat Komunitas Online dengan PHPBB.

Yogyakarta: ANDI.

Ibrahim. (2015). Metodologi Penelitian Kualitatif. Bandung: Alfabeta.

Indonesia Survei Center. (2020). Laporan Survei Internet APJII 2019-2020 (Q2). https://www.apjii.or.id/survei

Jumrad, O. T., \& Sari, I. D. M. (2019). Fungsi Komunikasi dalam Organisasi melalui Group Chat Whatsapp Oriflame. Jurnal Common, 3(1), 104-114.

Moleong, L. J. (2012). Metodologi Penelitian Kualitatif. Bandung: PT Remaja Rosdakarya.

Muhammad, A. (2017). Komunikasi Organisasi. Jakarta: Bumi Aksara

Mulyana, D. \& Solatun. (2008). Metode Penelitian Komunikasi. Bandung: Remaja Rosdakarya

Nasrullah, R. (2013). Cyber Media. Yogyakarta: Idea Press

Purnomo, A. (2018). Pelaksanaan kebijakan Komunikasi Organisasi Pemerintahan di Indonesia. Jurnal Noken, 3(2), 11-26.

Rahmansari, R. (2017). Penggunaan Aplikasi WhatsApp dalam Komunikasi Organisasi Pegawai Dinas Lingkungan Hidup dan Kebersihan Sidoarjo. Jurnal IImiah Manajemen Publik Dan Kebijakan Sosial, 1(2), 77-90.

Sedarmayanti. (2018). Komunikasi Pemerintahan. Bandung: Refika Aditama.

Whatsapp. (2020). Dipetik November 2020, dari About: http://whatsapp.com/about/

Whatsapp FAQ. (2020). Dipetik November 2020, dari General: https://faq.whatsapp.com/general/

We Are Social. (2020). Digital 2020: Indonesia. https://datareportal.com/reports/digital-2020-indonesia

Widjajanto, K. (2013). Perencanaan Komunikasi: Konsep dan Aplikasi. Bandung: Ultimus. 